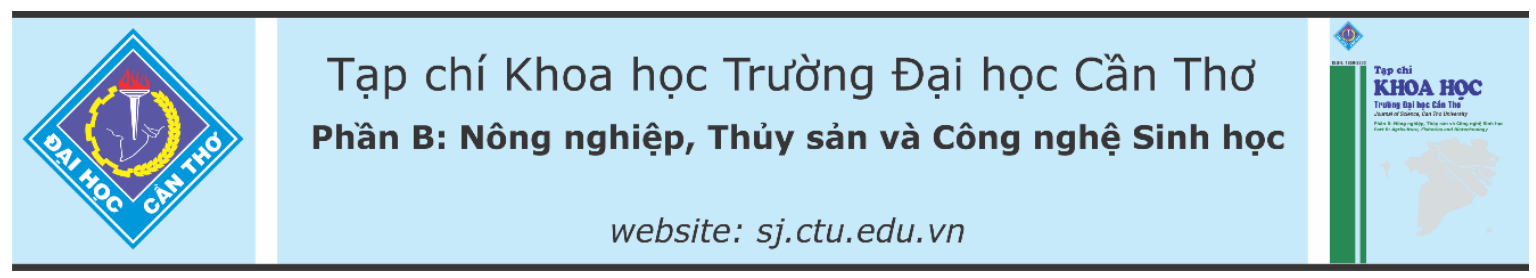

DOI:10.22144/ctu.jvn.2021.121

\title{
PHÂN LẬP VÀ TUYỂN CHỌN NẤM MEN ÚNG DỤNG TRONG LÊN MEN RƯợU VANG MÃNG CẦU XIÊM (Annona muricata L.)
}

Nguyễn Ngọc Thạnh ${ }^{1}$, Huỳnh Văn Kiệt ${ }^{2}$, Lê Trung Tín ${ }^{3}$, Lưu Minh Châu ${ }^{1}$, Đoàn Thị Kiều Tiên ${ }^{4}$ và Huỳnh Xuân Phong ${ }^{1 *}$

${ }^{1}$ Viện Nghiên cứu và Phát triển Công nghệ Sinh học, Truờng Đại học Cần Tho

${ }^{2}$ Học viên cao họ ngành Công nghệ Sinh học khoá 26, Truờng Đại học Cần Tho'

${ }^{3}$ Sinh viên ngành Công nghệ Sinh học khoá 42, Truờng Đại học Cần Tho

${ }^{4}$ Khoa Công nghệ Thưc phẩm và Công nghệ Sinh học, Trương Đại học Kỹ thuật - Công nghệ Cần Tho

*Nguoòi chịu trách nhiệm về bài viết: Huỳnh Xuân Phong (email: hxphong@ctu.edu.vn)

\section{Thông tin chung:}

Ngày nhận bài: $18 / 02 / 2021$

Ngày nhận bài sưa: 06/04/2021

Ngày duyệt đăng: 20/08/2021

\section{Title:}

Isolation and selection of fermentative yeasts for wine production from soursop (Annona murica L.)

\section{Tù khóa:}

Annona muricata, lên men rươu, nấm men, ruợu vang mãng cầu xiêm,

Saccharomyces cerevisiae

\section{Keywords:}

Annona muricata, ethanol fermentation, Saccharomyces cerevisiae, soursop wine, yeast

\begin{abstract}
Soursop (Annona murica L.) is known as a fruit that has a delicious and nutritious flavor but is easy to spoil and difficult to preserve. The study was carried out to isolate and select a yeast strain with good fermentation ability in the soursop fruit juice for application in soursop wine production. Thirty yeast strains were isolated and classified belonging to the two genera of Saccharomyces and Pichia. Of which, 4 yeast strains were selected and investigated the fermentation ability of soursop fruit juice (treated with $0.3 \%$ of pectinase for 1 hour and adjusted $\mathrm{pH}$ to 4 and $25^{\circ}$ Brix) for 9 days. The yeast strain FBY015 was selected based on the best fermentation ability with the highest achieved alcohol concentration $(10.70 \% \mathrm{v} / \mathrm{v})$. This yeast strain was identified as Saccharomyces cerevisiae.
\end{abstract}

\section{TÓM TẮT}

Mãng cầu xiêm (Annona murica L.) là một loại trái cây có huơng vị thơm ngon và bổ duõng nhung lại rất dế hu hỏng và khó bảo quản. Nghiên cưu được thực hiện nhằm phân lập và tuyển chọn được dòng nấm men có khả năng lên men dịch quả mãng cầu xiêm để úng dụng trong sản xuất ruợu vang mãng cầu xiêm. Kết quả đã phân lập được 30 dòng nấm men thuộc hai chi Saccharomyces và Pichia. So tuyển được 4 dòng nấm men triển vong để khảo sát khả năng lên men dịch quả (xử lý enzyme pectinase 0,3\% trong 1 giờ và điều chỉnh về pH 4 và $25^{\circ}$ Brix) trong thời gian 9 ngày. Kết quả đã tuyển chọn được dòng nấm men FBY015 có khả năng lên men tốt nhất với độ ruợu đạt $10,70 \%$ v/v và được định danh là Saccharomyces cerevisiae.

\section{GIỚI THIỆU}

Nấm men đóng vai trò rất quan trọng đời sống và hiện diện trong các quá trình chế biến thực phẩm, điển hình như lên men bánh mì, cơm rượu, rượu vang trái cây,... (Lương Đức Phẩm, 2009). Ở Việt Nam, rượu vang đang ngày càng phổ biến do có độ cồn nhe và mang những đặc tính tốt cho sức khỏe. Đồng thời, nguồn nguyên liệu cho sản xuất rượu vang ở nước ta cũng rất đa dạng và phong phú như 
nho, xoài, mãng cầu xiêm, cam, khóm, dưa hấu,... Trong đó, mãng cầu xiêm cũng là nguồn nguyên liệu đáng chú ý (Vũ Công Hậu, 2005). Mãng cầu xiêm là loại quả được sử dụng rộng rãi trong ngành công nghiệp thực phẩm để pha chế đồ uống, làm kem, sữa chua, mứt, sirô,... do có mùi thơm và vị dễ chịu lại giàu chất $\mathrm{xo}$, khoáng và vitamin $\mathrm{C}, \mathrm{B}_{1}$ và $\mathrm{B}_{2}$ (Coêlho de Lima \& Alves, 2011). Ngoài ra, quả mãng cầu xiêm còn có hàm lượng polyphenol cao với các đặc tính có lợi như chống ung thư và chống đái tháo đường (Bhat \& Paliyath, 2016). Tuy nhiên, mãng cầu xiêm tươi không được cung cấp thường xuyên do quả dễ hỏng và thời gian bảo quản sau thu hoạch ngắn (Coêlho de Lima \& Alves, 2011). Bên cạnh đó, các chủng nấm men với các đặc tính khác nhau sẽ tạo thành các chất dễ bay hơi có thành phần và tỷ lệ khác nhau trong sản phẩm lên men (Li et al., 2016). Do đó, tùy thuộc vào đặc điểm của từng loại nguyên liệu khác nhau thì sẽ có các chủng nấm men thích hợp với từng loại nguyên liệu để tạo ra rượu vang với hàm lượng ethanol cao và có hương vị thơm ngon, đặc trưng. Vì vậy, nghiên cứu phân lập và tuyển chọn chủng nấm men thích hợp để ứng dụng trong quá trình sản xuất rượu vang mãng cầu xiêm là cần thiết trong việc vừa đa dạng hoá sản phẩm, vừa nâng cao giá trị kinh tế và tận dụng nguồn nguyên liệu có giá trị cao nhưng khó bảo quản.

\section{VÂTT LIỆU VÀ PHƯƠNG PHÁP}

\subsection{Nguyên vật liệu và hóa chất}

Quả mãng cầu xiêm có gai nở rộng, vỏ vàng láng bóng, có mùi thơm được thu mua tại vườn. Quả mãng cầu được giữ trong thùng xốp và vận chuyển về phòng thí nghiệm trong ngày. Mẫu được sử dụng trong ngày hoặc trữ ở nhiệt độ $4^{\circ} \mathrm{C}$ trong $1-2$ ngày để phân lập nấm men.

Nấm men Saccharomyces cerevisiae RV100 và RV002 (các chủng thương mại được dùng cho đối chứng) được được lưu trữ ở phòng thí nghiệm Công nghệ Sinh học Thực phẩm, Viện Nghiên cứu và Phát triển Công nghệ Sinh học, Trường Đại học Cần Thơ.

Môi trường trường nuôi cấy và thử nghiệm đặc tính sinh hóa của nấm men gồm: YPD (yeast extract $0,5 \%$, peptone $0,5 \%$, glucose $2,0 \%$ ) và môi trường YPD agar (môi trường YPD bổ sung 1,5\% agar); môi trường Christensen (urea $20 \mathrm{~g} / \mathrm{L}$; yeast extract 0,1 g/L; $\mathrm{Na}_{2} \mathrm{HPO}_{4}$ 9,5 g/L; $\mathrm{K}_{2} \mathrm{HPO}_{4}$ 9,1 g/L; phenol red 0,01 g/L; pH 6,7) (Christensen, 1946).

Hóa chất sử dụng để điều chỉnh $\mathrm{pH}$ và phân tích chỉ tiêu gồm: $\mathrm{NaHSO}_{3}$, citric acid, $\mathrm{NaOH}, \mathrm{HCl}$, urea, D-glucose,... được mua từ các sản phẩm thương mại của Merck (Đức) và HiMedia Laboratories (Ấn Độ).

\subsection{Phân lập và định danh sơ bộ các dòng nấm men phân lập}

\subsubsection{Phân lập và xác định đặc điểm hình thái của nấm men}

Quả mãng cầu xiêm thu về không tách bỏ vỏ, loại bỏ những quả hư hỏng. Khoảng $5 \mathrm{~g}$ mẫu (bao gồm cả vỏ và thịt quả) được cho vào bình tam giác có chứa $100 \mathrm{~mL}$ môi trường YPD (đã được khử trùng ở $121^{\circ} \mathrm{C}$ trong 15 phút) để tăng sinh ở nhiệt độ phòng trong 24 giờ. Dịch tăng sinh $(100 \mu \mathrm{L})$ được cấy trải trên môi trường YPD agar. Chọn các khuẩn lạc nấm men khác nhau để tiếp tục cấy chuyền đến khi thu được khuẩn lạc nấm men thuần nhất. Kiểm tra độ thuần của tế bào nấm men dưới kính hiển vi. Phân loại sơ bộ đến mức độ giống các dòng nấm men phân lập dựa vào các đặc điểm về hình thái và sinh hóa cơ bản của nấm men các đặc điểm như: hình thái khuẩn lạc, hình thái tế bào, kiểu nẩy chồi, khả năng lên men đường saccharose và glucose, hoạt tính phân giải urea (Kurtzman et al., 2011).

\subsection{2. Đánh giá khả năng lên men đường glucose và saccharose}

Các dòng nấm men được phân lập và dòng nấm men nấm men đối chứng được tăng sinh trong môi trường YPD trên máy lắc ở nhiệt độ phòng trong 24 giờ (đạt mật số $10^{8}$ tế bào $/ \mathrm{mL}$ ). Cho $1 \mathrm{~mL}$ dịch tăng sinh nấm men vào ống nghiệm có chứa sẵn $9 \mathrm{~mL}$ dung dịch đường (glucose $2 \%$ và saccharose $2 \%$ ) và chuông Durham (đã được khử trùng ở $115^{\circ} \mathrm{C}$ trong 15 phút) và ủ lên men ở $30^{\circ} \mathrm{C}$. Đo cột khí $\mathrm{CO}_{2}$ trong chuông Durham bắt đầu từ 2 giờ cho đến khi $\mathrm{CO}_{2}$ đầy chuông Durham (chiều cao tối đa là $30 \mathrm{~mm}$ ), mỗi thời điểm cách nhau 2 giờ.

\subsection{3. Đánh giá khả năng phân giải urea}

Các dòng nấm men phân lập được tăng sinh trong môi trường YPD trên máy lắc ở nhiệt độ phòng trong 24 giờ. Cho $0,5 \mathrm{~mL}$ dịch tăng sinh nấm men đạt $10^{8}$ tế bào/mL vào ống nghiệm có chứa sẵn $4,5 \mathrm{~mL}$ môi trường Christensen (đã được khử trùng ở $115^{\circ} \mathrm{C}$ trong 15 phút) và ủ ở $30^{\circ} \mathrm{C}$ trong 1 tuần. Kết quả dương tính khi môi trường chuyển sang màu đỏ sẫm.

\subsection{Tuyển chọn dòng nấm men có hoạt lực lên men cao trong dịch mãng cầu xiêm}

Các dòng nấm men được phân lập và dòng đối chứng được tăng sinh trong môi trường YPD trên máy lắc ở nhiệt độ phòng trong 24 giờ (đạt mật số $10^{8} \mathrm{tb} / \mathrm{mL}$ ). Dịch quả mãng cầu xiêm được xử lý 
bằng enzyme pectinase $0,3 \%$ trong 1 giờ. Phối chế dịch quả mãng cầu bằng đường saccharose đến $25^{\circ}$ Brix, điều chỉnh $\mathrm{pH} 4$ và thanh trùng với $\mathrm{NaHSO}_{3}(140 \mathrm{mg} / \mathrm{L})$ trong 2 giờ. Cho $1 \mathrm{~mL}$ dịch tăng sinh nấm men vào bình tam giác có chứa sẵn $99 \mathrm{~mL}$ dịch quả đã được xử lý. Đậy kín bằng waterlock và theo dõi quá trình lên men và phân tích các chỉ tiêu khi kết thúc quá trình lên men.

\section{4. Định danh dòng nấm men bằng phương pháp sinh học phân tử}

Dòng nấm men có hoạt lực lên men mạnh nhất được tuyển chọn để định danh bằng kỹ thuật sinh học phân tử. DNA tổng số của nấm men được tách chiết theo mô tả của Harju et al. (2004) và phản ứng PCR được thực hiện sử dụng cặp mồi ITS1 (5'TCCGTAGGTGAACCTGCGG-3') và ITS4 (5'TCCTCCGCTTATTGATATGC-3') (Martin \& Rygiewicz, 2005). Sử dụng chương trình Nucleotide Blast để so sánh mức độ tương đồng của trình tự được giải với trình tự của các dòng nấm men trong ngân hàng gene NCBI với công cụ BLAST.

\subsection{Phân tích và xử lý số liệu}

Kết quả được xử lý và vẽ biểu đồ bằng phần mềm Microsoft Excel 2013 (Microsoft Corporation, Hoa Kỳ). Số liệu được xử lý thống kê bằng phần mềm Statgraphics Centurion XVI (Statpoint Technologies Inc., Hoa Kỳ).

\section{KẾT QUẢ VÀ THẢO LUẬN}

\subsection{Kết quả phân lập và định danh sơ bộ các dòng nấm men từ mãng cầu xiêm}

\subsection{1. Đặc điểm hình thái của nấm men phân lập}

Kết quả đã phân lập được 30 dòng nấm men thuần chủng với 6 nhóm hình dạng tế bào khác nhau bao gồm hình cầu lớn, cầu nhỏ, hình oval lớn, oval nhỏ, hình elip dài và elip ngắn (Bảng 1 ).

Bảng 1. Đặc điểm hình thái các chủng nấm men phân lập từ mãng cầu xiêm

\begin{tabular}{|c|c|c|c|}
\hline Nhóm & Dòng nấm men & Hình dạng khuẩn lạc & Hình dạng tế bào \\
\hline 1 & FBY028, FBY029 & $\begin{array}{l}\text { Khuẩn lạc hình tròn, màu trắng sữa, độ } \\
\text { nổi mô, bìa nguyên, bề mặt nhẵn và ướt }\end{array}$ & Cầu lớn \\
\hline 2 & $\begin{array}{l}\text { FBY013, FBY018, FBY030, } \\
\text { FBY031, FBY032, FBY033, } \\
\text { FBY037 }\end{array}$ & $\begin{array}{l}\text { Khuẩn lạc hình tròn, màu trắng sữa, độ } \\
\text { nồi mô thấp, bìa nguyên, bề mặt nhẵn } \\
\text { và khô }\end{array}$ & Cầu nhỏ \\
\hline 3 & $\begin{array}{l}\text { FBY014, FBY015, FBY019, } \\
\text { FBY024, FBY036 }\end{array}$ & $\begin{array}{l}\text { Khuẩn lạc hình tròn, màu trắng sữa, độ } \\
\text { nồi mô, bìa nguyên, bề mặt nhẵn và } \\
\text { bóng }\end{array}$ & Oval lớn \\
\hline 4 & $\begin{array}{l}\text { FBY012, FBY016, FBY017, } \\
\text { FBY020, FBY022, FBY023, } \\
\text { FBY027, FBY038, FBY039, } \\
\text { FBY040, FBY041 }\end{array}$ & $\begin{array}{l}\text { Khuẩn lạc hình tròn, màu trắng sữa, độ } \\
\text { nổi mô, bìa nguyên, bề mặt nhẵn và ướt }\end{array}$ & Oval nhỏ \\
\hline 5 & FBY025, FBY026 & $\begin{array}{l}\text { Khuẩn lạc không đều, màu trắng đục, } \\
\text { độ nổi bướu, bìa chia và bề mặt khô }\end{array}$ & Elip dài \\
\hline 6 & FBY021, FBY034, FBY035 & $\begin{array}{l}\text { Khuẩn lạc hình tròn, màu trắng đục, độ } \\
\text { nổi bướu, bìa răng cưa và bề măt khô }\end{array}$ & Elip ngắn \\
\hline
\end{tabular}

Theo Lương Đức Phẩm (2009), tế bào nấm men có hình dạng phổ biến như hình cầu, hình oval, hình elip, hình trụ hoặc đôi khi kéo dài thành hình sợi. Nấm men có thể thay đổi hình dạng và kích thước trong các giai đoạn phát triển và điều kiện môi trường xung quanh. Bảng 1 cho thấy sự đa dạng về hình dạng tế bào của các dòng nấm men phân lập. Hình dạng các chủng nấm men phân lập được cũng khá đa dạng như trong nghiên cứu phân lập nấm men của Đoàn Thị Kiều Tiên và ctv. (2018), Huỳnh Ngọc Thanh Tâm và ctv. (2018),...
Hình dạng khuẩn lạc nấm men có các đặc điểm chung là tròn đều, bề mặt bóng, dạng mô nổi và bìa nguyên với màu sắc chủ yếu là trắng ngà và trắng sữa. Bên cạnh đó, cũng có những khuẩn lạc không đều, bìa chia thùy và bìa răng cưa. Kết quả quan sát hình thức nảy chồi của tế bào nấm men cho thấy có hai hình thức là nảy chồi nhiều hướng và nảy chồi lưỡng cực. Trong đó, các nhóm $1,2,3$ và 4 có hình thức nảy chồi nhiều hướng, còn tế bào thuộc nhóm 5 và 6 có hình thức nảy chồi lưỡng cực (Hình 1). 

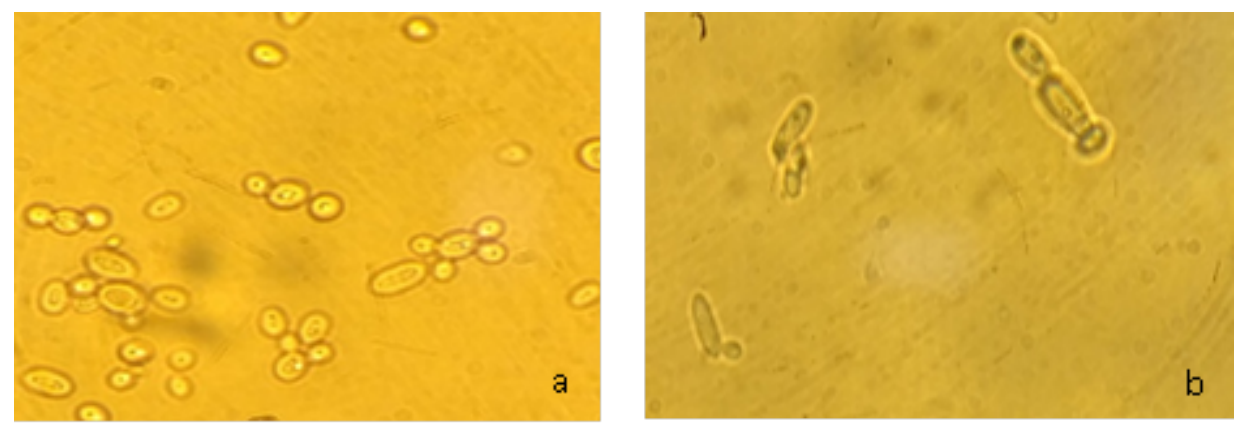

Hình 1. Hình thức nảy chồi của các nhóm nấm men (a: nhiều hướng; b: lưỡng cực)

\subsubsection{Khả năng lên men glucose và saccharose}

Nhằm đánh giá khả năng lên men dung dịch glucose $2 \%$ và saccharose $2 \%$ của các dòng nấm men bằng phương pháp lên men trong chuông
Durham. Ba mươi dòng nấm men được phân lập có các hình dạng khác nhau được chọn để khảo sát và kết quả chiều cao cột khí $\mathrm{CO}_{2}$ được tổng hợp ở Bảng 2.

Bảng 2. Chiều cao cột khí $\mathrm{CO}_{2}(\mathrm{~mm})$ trong chuông Durham của các chủng nấm men

\begin{tabular}{|c|c|c|c|c|c|c|c|c|c|c|c|c|c|c|}
\hline \multirow{3}{*}{ Dòng } & \multicolumn{14}{|c|}{ Chiều cao cột khí $\mathrm{CO}_{2}(\mathrm{~mm})$ trong chuông Durham theo thời gian lên men (giờ) } \\
\hline & \multicolumn{7}{|c|}{ Glucose 2\% } & \multicolumn{7}{|c|}{ Saccharose $2 \%$} \\
\hline & 2 & 4 & 6 & 8 & 10 & 12 & 14 & 2 & 4 & 6 & 8 & 10 & 12 & 14 \\
\hline FBY012 & - & 1 & 2 & 4 & 7 & 9 & 12 & 1 & 1 & 1 & 4 & 6 & 15 & 17 \\
\hline FBY013 & - & - & - & - & 1 & 2 & 4 & - & - & - & - & 3 & 6 & 10 \\
\hline FBY028 & - & - & - & 1 & 1 & 2 & 3 & - & - & - & - & 1 & 2 & 4 \\
\hline FBY014 & - & 1 & 2 & 4 & 7 & 14 & 18 & - & 1 & 2 & 8 & 12 & 23 & 30 \\
\hline FBY026 & - & - & - & - & - & - & - & - & - & - & - & - & 1 & 1 \\
\hline FBY029 & - & - & - & - & 1 & 3 & 4 & 2 & 2 & 3 & 6 & 10 & 16 & 17 \\
\hline FBY037 & 1 & 1 & 1 & 3 & 4 & 5 & 6 & - & - & - & 2 & 3 & 3 & 4 \\
\hline FBY038 & - & 1 & 3 & 6 & 9 & 10 & 12 & 2 & 2 & 4 & 7 & 7 & 10 & 13 \\
\hline FBY030 & - & - & - & 1 & 2 & 2 & 3 & - & 1 & 2 & 2 & 2 & 2 & 4 \\
\hline FBY016 & - & - & 1 & 3 & 5 & 7 & 9 & - & 1 & 2 & 3 & 4 & 8 & 11 \\
\hline FBY017 & - & - & 2 & 4 & 7 & 9 & 11 & - & 1 & 2 & 4 & 6 & 6 & 8 \\
\hline FBY018 & - & - & - & - & 1 & 4 & 4 & - & 1 & 1 & 2 & 3 & 4 & 7 \\
\hline FBY031 & - & - & 1 & 2 & 1 & 3 & 4 & 1 & 1 & 2 & 3 & 3 & 4 & 5 \\
\hline FBY032 & - & 1 & 2 & 4 & 4 & 5 & 7 & - & 1 & 1 & 2 & 3 & 4 & 6 \\
\hline FBY019 & 2 & 4 & 10 & 18 & 30 & 30 & 30 & - & 1 & 2 & 9 & 17 & 30 & 30 \\
\hline FBY020 & - & - & 2 & 5 & 9 & 16 & 22 & 2 & 3 & 5 & 9 & 15 & 30 & 30 \\
\hline FBY039 & - & 1 & 1 & 2 & 2 & 3 & 4 & - & - & - & 2 & 3 & 4 & 5 \\
\hline FBY033 & - & - & - & - & 1 & 2 & 3 & - & - & - & 2 & 4 & 5 & 6 \\
\hline FBY021 & - & - & - & - & - & - & - & - & - & - & - & 1 & 2 & 2 \\
\hline FBY040 & - & - & - & - & 1 & 4 & 5 & - & - & - & 2 & 3 & 5 & 7 \\
\hline FBY022 & - & - & - & 2 & 2 & 3 & 4 & - & - & - & 3 & 5 & 7 & 8 \\
\hline FBY023 & - & - & 1 & 2 & 4 & 4 & 5 & - & - & 1 & 1 & 2 & 2 & 3 \\
\hline FBY024 & - & 1 & 3 & 6 & 9 & 16 & 18 & 1 & 2 & 4 & 6 & 11 & 21 & 30 \\
\hline FBY034 & - & - & - & - & - & - & - & - & - & 1 & 1 & 2 & 2 & 3 \\
\hline FBY025 & - & - & - & - & - & - & - & - & - & - & - & - & 1 & 2 \\
\hline FBY035 & - & - & - & - & - & - & - & - & - & - & - & 1 & 1 & 2 \\
\hline FBY015 & 1 & 3 & 8 & 13 & 22 & 30 & 30 & 3 & 5 & 22 & 30 & 30 & 30 & 30 \\
\hline FBY036 & - & 3 & 13 & 26 & 30 & 30 & 30 & - & 2 & 9 & 30 & 30 & 30 & 30 \\
\hline FBY041 & - & - & - & 1 & 1 & 4 & 5 & - & - & - & 3 & 5 & 7 & 8 \\
\hline FBY027 & - & - & 2 & 4 & 6 & 9 & 11 & - & - & 2 & 7 & 9 & 13 & 14 \\
\hline
\end{tabular}

*Ghi chú: Dấu“-“ không xuất hiện khi trong chuông durham, chiều cao chuông Durham là 30 mm. 
Trong quá trình lên men rượu, 2 sản phẩm chính thu được là rượu ethanol và $\mathrm{CO}_{2}$, để xác định hoạt lực lên men có thể dựa trên khả năng thoát khí $\mathrm{CO}_{2}$ trong quá trình lên men (Nguyễn Đức Lượng, 2003). Vì thế, có thể dựa vào thời gian đầy chuông Durham sớm nhất, để xác định dòng nấm men có hoạt lực lên men manh. Bảng 2 cho thấy khi lên men trong dung dịch saccharose $2 \%$ thì sau 2-4 giờ đầu, hầu hết các dòng nấm men chưa có dấu hiệu lên men hoặc lên men rất yếu. Kể từ sau 8 giờ lên men thì cột khí $\mathrm{CO}_{2}$ bắt đầu tăng, trừ các dòng FBY013, FBY029, FBY018, FBY033 và FBY040. Sau 14 giờ khảo sát thì có 4 dòng nấm men sinh khí $\mathrm{CO}_{2}$ đáng kể bao gồm FBY019, FBY020, FBY015, FBY036 với cột khí cao lần lượt là $30 \mathrm{~mm}, 22 \mathrm{~mm}, 30 \mathrm{~mm}$ và $30 \mathrm{~mm}$. Riêng các dòng nấm men FBY026, FBY022, FBY034, FBY025 và FBY035 hoàn toàn không có khả năng lên men vì không có xuất hiện khí $\mathrm{CO}_{2}$ trong chuông Durham.

Tương tự, khi lên men trong dung dịch glucose $2 \%$, từ sau 8 giờ thì cột khí $\mathrm{CO}_{2}$ cũng bắt đầu tăng. Tuy nhiên, toàn bộ các dòng nấm men phân lập được đều có khả năng sử dụng glucose làm nguồn cơ chất. Trong đó, các dòng FBY014, FBY019, FBY020,
FBY024, FBY015 và FBY036 có chiều cao khí trong chuông Durham đạt tối đa sau 14 giờ. Có thể thấy rằng, sau khi thử nghiệm khả năng lên men của các tất cả các dòng nấm men trong cả 2 dung dịch glucose $2 \%$ và saccharose $2 \%$ thì có $4 / 30$ dòng (gồm FBY015, FBY019, FBY020 và FBY036) có khả năng lên men tốt nhất khi chiều cao cột khí đã bắt đầu đạt tối đa chỉ sau 10 giờ.

\subsubsection{Khả năng phân giải urea}

Màu sắc của môi trường Christensen có sự thay đổi là do nấm men có khả năng sinh enzyme urease để phân giải urea thành $\mathrm{CO}_{2}$ và $\mathrm{NH}_{3}$, lượng $\mathrm{NH}_{3}$ tăng lên làm $\mathrm{pH}$ tăng khiến môi trường chuyển sang màu đỏ thông qua chất chỉ thị màu phenol red. Kết quả quan sát sự chuyển màu được thể hiện ở Bảng 3 cho thấy có 5 dòng nấm men có khả năng phân giải urea làm cho môi trường Christesen chuyển sau màu đỏ gồm có FBY021, FBY025, FBY026, FBY034 và FBY035. Năm dòng này thuộc nhóm 5 (elip dài) và nhóm 6 (elip ngắn). Các dòng còn lại không có khả năng phân giải urea thuộc nhóm 1 (cầu lớn), nhóm 2 (cầu nhỏ), nhóm 3 (oval lớn) và nhóm 4 (oval nhỏ).

Bảng 3. Khả năng phân giải urea của 30 dòng nấm men sau 7 ngày khảo sát

\begin{tabular}{clc}
\hline Nhóm & Dòng nấm men & Khả năng phân giải urea \\
\hline 1 & FBY028, FBY029 & - \\
2 & FBY013, FBY018, FBY030, FBY031, FBY032, FBY033, & - \\
3 & FBY037 & - \\
4 & FBY014, FBY015, FBY019, FBY024, FBY036 & - \\
5 & FBY038, FBY016, FBY017, FBY020, FBY022, FBY027, & + \\
6 & FBY021, FBY25, FBY040, FBY041 & + \\
\hline
\end{tabular}

*Ghi chú: Dấu (+) là duơng tính, dấu (-) là âm tính

Kết quả khảo sát các đặc điểm hình thái và đặc điểm sinh lý, sinh hóa của 30 dòng nấm men phân lập được định danh sơ bộ theo Kurtzman et al. (2011) được trình bày trong Bảng 4 . Dựa vào kết quả khảo sát các đặc điểm hình thái và đặc điểm sinh lý, sinh hóa của 30 dòng nấm men phân lập được, có thể định danh sơ bộ như sau: các dòng nấm men thuộc nhóm $1,2,3$ và 4 là các dòng nấm men thuộc chi Saccharomyces. Các dòng nấm men thuộc chi này có khả năng lên men cả đường glucose và saccharose, tuy nhiên không có khả năng phân giải urea. Còn các dòng nấm men thuộc nhóm 5 và 6 thuộc chi Pichia, các dòng này không có khả năng lên men đường saccharose nhưng có khả năng phân giải urea.

Như vậy, 30 dòng nấm men được phân lập thuộc 2 chi nấm men Saccharomyces ( 25 dòng) và Pichia ( 5 dòng). Kết quả đạt được từ nghiên cứu này có sự tương đồng với kết quả của Nguyễn Văn Thành và ctv. (2013) khi phân lập nấm men từ khóm với 13 dòng thuộc Saccharomyces và 4 dòng thuộc Pichia. Cùng năm 2013, Nguyễn Minh Thủy và ctv. đã phân lập nấm men từ sim rừng và định danh sơ bộ thì đều xuất hiện 2 giống nấm men này. 
Bảng 4. Đặc điểm hình thái và đặc điểm sinh lý, sinh hóa của 30 dòng nấm men phân lập

\begin{tabular}{|c|c|c|c|c|c|c|}
\hline \multirow{3}{*}{$\begin{array}{l}\text { Dòng } \\
\text { nấm } \\
\text { men }\end{array}$} & \multicolumn{2}{|c|}{ Đặc điểm hình thái } & \multicolumn{3}{|c|}{ Đăc điểm sinh lý sinh hóa } & \multirow{3}{*}{$\begin{array}{l}\text { Phân loại so' } \\
\text { bộ }\end{array}$} \\
\hline & \multirow{2}{*}{$\begin{array}{l}\text { Hình dạng } \\
\text { tế bào }\end{array}$} & \multirow{2}{*}{$\begin{array}{l}\text { Hình thức } \\
\text { nảy chồi }\end{array}$} & \multicolumn{2}{|c|}{ Khả năng lên men đường } & \multirow{2}{*}{$\begin{array}{c}\text { Phân giải } \\
\text { urea }\end{array}$} & \\
\hline & & & Glucose & Saccharose & & \\
\hline Nhóm 1 & Cầu lớn & Nhiều hướng & + & + & - & Saccharomyces \\
\hline Nhóm 2 & Cầu nhỏ & Nhiều hướng & + & + & - & Saccharomyces \\
\hline Nhóm 3 & Oval lớn & Nhiều hướng & + & + & - & Saccharomyces \\
\hline Nhóm 4 & Oval nhỏ & Nhiều hướng & + & + & - & Saccharomyces \\
\hline Nhóm 5 & Elip dài & Lưỡng cực & + & - & + & Pichia \\
\hline Nhóm 6 & Elip ngắn & Lưỡng cực & + & - & + & Pichia \\
\hline
\end{tabular}

*Ghi chú: Dấu (+) là duoơng tính,, dấu (-) là âm tính

\subsection{Tuyển chọn dòng nấm men có hoạt lực lên men dịch mãng cầu xiêm}

Bốn dòng nấm men FBY019, FBY020, FBY015 và $\mathrm{FBY} 036$ được sơ tuyển từ khả năng lên men trong chuông Durham cùng với 2 chủng đối chứng $S$. cerevisiae RV002 và RV100 được sử dụng để đánh giá khả năng lên men dịch quả mãng cầu xiêm. Kết quả các chỉ tiêu trong quá trình lên men dịch quả mãng cầu xiêm được trình bày ở Bảng 5 .

\section{Bảng 5. Khả năng lên men dịch quả mãng cầu xiêm của các chủng nấm men}

\begin{tabular}{lrrr}
\hline Dòng nấm men & pH sau lên men & Độ Brix sau lên men ( ${ }^{\mathbf{0}}$ Brix) & Độ rượu (\% v/v) \\
\hline FBY015 & 3,79 & $8,67^{\mathrm{b}} \pm 0,577$ & $10,70^{\mathrm{a}} \pm 0,393$ \\
FBY019 & 3,74 & $11,33^{\mathrm{a}} \pm 0,577$ & $9,04^{\mathrm{c}} \pm 0,168$ \\
FBY020 & 3,77 & $9,50^{\mathrm{b}} \pm 0,500$ & $9,78^{\mathrm{abc}} \pm 0,255$ \\
FBY036 & 3,77 & $9,67^{\mathrm{b}} \pm 0,577$ & $9,92^{\mathrm{abc}} \pm 0,486$ \\
RV002 & 4,18 & $9,17^{\mathrm{b}} \pm 0,289$ & $9,69^{\mathrm{bc}} \pm 0,127$ \\
RV100 & 4,16 & $8,83^{\mathrm{b}} \pm 0,764$ & $10,16^{\mathrm{ab}} \pm 0,537$ \\
\hline
\end{tabular}

* Ghi chú: Giá trị trong bảng là trung bình của 3 lần lặp lại, trong cùng một cột các chũ số mũ giống nhau thì khác biệt không có ý nghĩa thống kê $5 \%(P<0,05)$. Giá trị sau giá trị trung bình biểu thị độ lệch chuẩn.

Dựa vào độ rượu và độ Brix sau lên men các mẫu rượu trong cùng một điều kiện lên men (dịch quả ở $25^{\circ}$ Brix, $\mathrm{pH} 4$ và mật số tế bào nấm men $10^{8} \mathrm{tb} / \mathrm{mL}$ ) trong 9 ngày cho thấy sau quá trình lên men, $\mathrm{pH}$ sau lên men đều giảm so với dịch quả ban đầu. Điều này có thể giải thích rằng, hoạt động của nấm men trong quá trình lên men kỵ khí sinh $\mathrm{ra} \mathrm{CO}_{2}$ và một số acid hữu cơ làm giảm $\mathrm{pH}$ của dịch lên men (Lương Đức Phẩm, 2009).

Bên cạnh đó, có thể thấy độ Brix sau khi lên men của sản phẩm cũng giảm so với độ Brix ban đầu. Việc giảm Brix cho thấy một lượng lớn đường đã được sử dụng cho quá trình lên men rượu, trong đó, theo lý thuyết có khoảng $10 \%$ glucose được sử dụng để nấm men tăng sinh khối và phần còn lại được chuyển hóa thành rượu và một số sản phẩm phụ khác (Lương Đức Phẩm, 2009). Cụ thể là ở dòng FBY015, hàm lượng ethanol sinh ra đạt $10,70 \% \mathrm{v} / \mathrm{v}$ và độ Brix giảm còn $8,67^{\circ}$ Brix, trong khi dòng FBY019 có hàm lượng ethanol chỉ đạt $9,04 \% \mathrm{v} / \mathrm{v}$ và độ Brix giảm còn đến $11,33^{\circ}$ Brix.

Độ rượu sau lên men thể hiện khả năng chuyển hóa đường thành rượu và hiệu suất lên men của các dòng nấm men. Độ rượu càng cao chứng tỏ hoạt lực lên men của nấm men càng mạnh do lượng ethanol sinh ra nhiều. Trong đó, các dòng FBY015, FBY020, FBY036 và RV100 sinh hàm lượng ethanol nằm trong khoảng từ $9,78 \%$ đến $10,70 \% \mathrm{v} / \mathrm{v}$ và khác biệt không có ý nghĩa về mặt thống kê với độ tin cậy 95\%. Riêng dòng FBY019 là khác biệt có ý nghĩa thống kê so với các chủng còn lại do hàm lượng ethanol sinh ra thấp nhất, chỉ đạt $9,04 \% \mathrm{v} / \mathrm{v}$. Kết quả ở thí nghiệm này cao hơn so với nghiên cứu của Nguyễn Thị Niềm và ctv. (2018) khi lên men rượu cà na bằng dòng nấm men $\mathrm{R} 2 \mathrm{~B}$ cho hàm lượng ethanol cao nhất chỉ đạt $7,51 \%$. Theo kết quả nghiên cứu của Nguyễn Phúc Trường (2011), khi lên men rượu vang cam và Phạm Thị Thu Thảo và ctv. (2019) trong lên men rượu vang thanh long ruột đỏ cũng có kết quả tương đồng. Tuy nhiên, kết quả này thấp hơn so với kết quả nghiên cứu của Nguyễn Văn Vũ và Nguyễn Văn Thành (2018) khi lên men dịch của dâu Hạ Châu bằng dòng nấm men $\mathrm{CB} 1.1$, sản phẩm sau lên men có hàm lượng ethanol đạt $12,71 \%$ $\mathrm{v} / \mathrm{v}$.

Kết quả khảo sát khả năng lên men dịch quả mãng cầu xiêm ở Bảng 5 cho thấy dòng nấm men FBY015 có khả năng lên men cho độ rượu cao nhất 
$(10,70 \% \mathrm{v} / \mathrm{v})$ nhưng khác biệt không có ý nghĩa so với các dòng còn lại, mặc dù hàm lượng ethanol của dòng FBY015 cao hơn cả 2 dòng nấm men đối chứng là $\mathrm{RV002}(9,69 \% \mathrm{v} / \mathrm{v})$ và $\mathrm{RV} 100(10,16 \%$ $\mathrm{v} / \mathrm{v})$. Do đó, kết quả cảm quan cũng là một trong những chỉ tiêu để đánh giá chất lượng của rượu vang. Rượu vang mãng cầu xiêm được lên men bởi dòng FBY015 có mùi vị đặc trưng của quả mãng cầu xiêm, không có mùi vị lạ, không bị vẫn đục và đáp ứng theo yêu cầu về cảm quan theo tiêu chuẩn quốc gia về rượu vang theo TCVN 7045:2013 (Bộ Khoa học và Công nghệ, 2013). Do đó, dòng nấm men FBY015 đã được tuyển chọn để định danh cũng như định hướng ứng dụng trong lên men rượu vang mãng cầu xiêm.

\section{3. Định danh dòng nấm men tuyển chọn bẳng kỹ thuật sinh học phân từ}

Dòng nấm men FBY015 được định danh bằng phương pháp giải trình tự và phân tích trình tự gene $28 \mathrm{~S}$ rRNA. Kết quả giải trình tự trên đoạn gene $28 \mathrm{~S}$ rRNA của dòng nấm men FBY015 như sau:

ATTATATTTTGAATGGATTTTTTTGTTTT GGCAAGAGCATGAGAGCTTTTACTGGGCA AGAAGACMARAGATGGAGAGTCCAGCCGG GCCTGCGCTTAAGTGCGCGGTCTTGCTAGG CTTGTAAGTTTCTTTCTTGCTATTCCAAACG GTGAGAGATTTCTGTGCTTTTGTTATAGGA CAATTAAAACCGTTTCAATACAACACACTG TGGAGTTTTCATATCTTTGCAACTTTTTCTT TGGGCATTCGAGCAATCGGGGCCCAGAGG TAACAAACACAAACAATTTTATCTATTCAT TAAATTTTTGTCAAAAACAAGAATTTTCGT AACTGGAAATTTTAAAATATTAAAAACTTT
CAACAACGGATCTCTTGGTTCTCGCATCGA TGAAGAACGCAGCGAAATGCGATACGTAA TGTGAATTGCAGAATTCCGTGAATCATCGA ATCTTTGAACGCACATTGCGCCCCTTGGTA TTCCAGGGGGCATGCCTGTTTGAGCGTCAT TTCCTTCTCAAACATTCTGTTTGGTAGTGAG TGATACTCTTTGGAGTTAACTTGAAATTGC TGGCCTTTTCATTGGATGTTTTTTTTCCAAA GAGAGGTTTCTCTGCGTGCTTGAGGTATAA TGCAAGTACGGTCGTTTTAGGTTTTACCAA CTGCGGCTAATCTTTTTTTATACTGAGCGTA TTGGAACGTTATCGATAAGAAGAGAGCGTC TAGGCGAACAATGTTCTTAAAGTTTGACCT CAAATCAGGTAGGAGTACCCGCTGAACTTA AGCATATCAWAAGGGGG

Đoạn gene này có 823 base nitrogen được so sánh với các gene $28 \mathrm{~S}$ rRNA của nấm men trong ngân hàng gene NCBI với công cụ BLASTN. Kết quả cho thấy đoạn gene $28 \mathrm{~S}$ rRNA của dòng nấm men FBY015 có độ tương đồng đến $99,37 \%$ so với trình tự gene $28 \mathrm{~S}$ rRNA của Saccharomyces cerevisiae (KX434760.1) (Hình 2). Như vậy, kết quả định danh có thể xác định dòng nấm men FBY015 là $S$. cerevisiae. Đây là chủng nấm men được phân lập từ trong các sản phẩm lên men dịch quả tự nhiên như khóm, sim, thanh long,... (Nguyễn Minh Thủy và ctv., 2013; Nguyễn Văn Thành và ctv., 2013; Huỳnh Xuân Phong và ctv., 2017; Phạm Thị Thu Thảo và ctv., 2019). Chủng nấm men này cũng được sử dụng rộng rãi trong ngành công nghiệp thực phẩm để sản xuất cồn, rượu, bia, nước giải khát lên men (Lương Đức Phẩm, 2009; Querol \& Bond, 2009; Radecka et al., 2015).

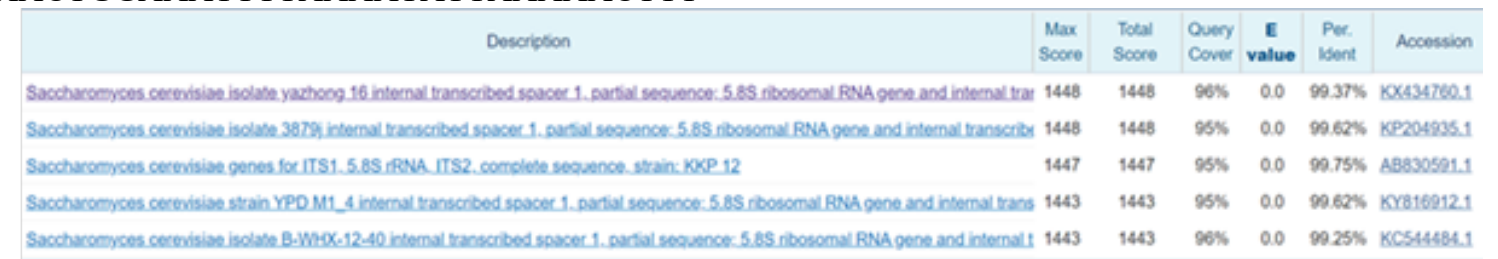

Saccharomyces cerevisiae isolate yazhong 16 internal transcribed spacer 1, partial sequence; 5.8S ribosomal RNA gene and internal transcribed spacer 2, complete sequence; and large subunit ribosomal RNA gene, partial sequence Sequence ID: KX434760.1 Length: 818 Number of Matches: 1

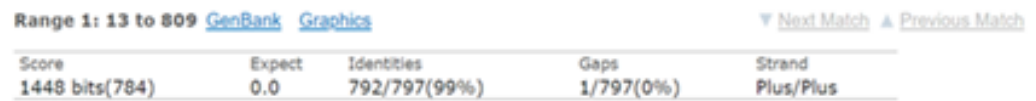

Hình 2. So sánh trình tự gene $28 S$ rRNA của FBY015 và chủng $S$. cerevisiae (số đăng ký KX434760.1)

\section{KẾT LUẬN}

Ba mươi dòng nấm men đã được phân lập từ mãng cầu xiêm với 6 nhóm hình dạng bao gồm cầu lớn, cầu nhỏ, oval lớn, oval nhỏ, elip dài và elip ngắn. Kết quả định danh sơ bộ thuộc hai giống nấm men là Saccharomyces (25 dòng) và Pichia (5 dòng). Từ 30 dòng nấm men phân lập, đã tuyển chọn được dòng nấm men FBY015 có hoạt lực lên men mạnh nhất với độ rượu $10,70 \%(\mathrm{v} / \mathrm{v})$ sau 9 ngày lên 
men và được định danh là Saccharomyces cerevisiae.

\section{TÀI LIỆU THAM KHẢO}

Bhat, R. \& Paliyath, G. (2016). Fruits of tropical climates: Dietary importance and health benefits. In B. Caballero, P. M. Finglas, \& F. Toldrá (Eds.), Encyclopedia of food and health (pp. 144149). Academic Press.

Bộ Khoa học và Công nghệ (2013). Tiêu chuẩn Việt Nam TCVN 7045:2013 về ruợu vang.

Christensen, W. B. (1946). Urea decomposition as a means of differentiating proteus and paracolon cultures from each other and from Salmonella and Shigella types. Journal of Bacteriology, 52(4), 461-466.

Coêlho de Lima, M. A., \& Alves, R. E. (2011). Soursop (Annona muricata L.). In E. M. Yahia (Eds.), Postharvest biology and technology of tropical and subtropical fruits: Mangosteen to white sapote (pp. 363-392e). Woodhead Publishing.

Đoàn Thị Kiều Tiên, Lữ Hằng Nghi, Nguyễn Ngọc Thạnh, Huỳnh Xuân Phong, Hà Thanh Toàn và Ngô Thị Phương Dung (2018). Phân lập và tuyển chọn nấm men chịu nhiệt lên men rượu vang trái giác (Cayratia trifolia L.). Tap chí Khoa học Kỹ thuật Nông lâm nghiệp, 2, 55-64.

Harju, S., Fedosyuk, H., \& Peterson, K. R. (2004). Rapid isolation of yeast genomic DNA: Bust n' Grab. BMC Biotechnology, 4, 8.

Huỳnh Ngọc Thanh Tâm, Nguyễn Đức Độ, Nguyễn Thị Niềm và Nguyễn Thị Minh Trâm (2018). Phân lập, tuyển chọn nấm men và xác định điều kiện ảnh hưởng đến quá trình lên men rượu cà na (Canarium album). Tap chi Khoa học \& Công nghệ Nông nghiệp, 2, 741-750.

Huỳnh Xuân Phong, Danh Minh Lợi, Nguyễn Ngọc Thạnh, Lê Phan Đình Quí, Bùi Hoàng Đăng Long, Pornthap Thanonkeo, Mamoru Yamada và Ngô Thị Phương Dung (2017). Tuyển chọn nấm men chịu nhiệt và nghiên cứu điều kiện lên men rượu vang khóm. Tap chí Khoa học Truờng Đại hoc Cần Tho, 51, 7-15.

Kurtzman, C. P., Fell, J. W., Boekhout, T., \& Robert, V. (2011). Methods for isolation, phenotypic characterization and maintenance of yeasts. In C. P. Kurtzman, J. W. Fell, \& T. Boekhout (Eds.), The yeasts: A taxonomic study (pp. 87-110). San Diego: Elsevier B.V.

Li, X., Yu, B., Curran, P. \& Liu, S. Q. (2016). Chemical and volatile composition of mango wines fermented with different Saccharomyces cerevisiae yeast strains. South African Journal of Enology and Viticulture, 32(1), 117-128.
Lương Đức Phẩm (2009). Nấm men công nghiẹp. Nhà xuất bản Khoa học và Kỹ thuật, Hà Nội.

Martin, K. J. \& Rygiewicz, P. T. (2005). Fungalspecific PCR primers developed for analysis of the ITS region of environmental DNA extracts. BMC Microbiology, 5(28), 1-11.

Nguyễn Đức Lượng (2003). Công nghệ vi sinh, tập 3. Thưc phẩm lên men truyền thống. Nhà xuất bản Đại học Quốc gia TP. HCM.

Nguyễn Minh Thủy, Nguyễn Văn Thành và Phạm Thị Ngọc Ánh (2013). Phân lập và tuyển chọn nấm men từ sim rừng ở Phú Quốc (Kiên Giang) và Măng Đen (Kontum). Kỷ yếu Hội thảo Công nghệ sinh hoc vùng Đồng bằng sông Cưu Long 2013 (pp. 47-53). Nhà xuất bản Đại học Cần Thơ.

Nguyễn Phúc Trường (2011). Phân lập và tuyển chon nấm men lên men tự nhiên dùng sản xuất ruợu vang cam (luận văn thạc sĩ). Trường Đại học Cần Thơ.

Nguyễn Thị Niềm, Huỳnh Ngọc Thanh Tâm và Nguyễn Đức Độ (2018). Phân lập và tuyển chọn dòng nấm men (Saccharomyces sp.) lên men rượu cà na (Canarium album). Tạp chi Khoa hoc Truờng Đại học Cần Tho, 54(1), 44-49.

Nguyễn Văn Thành, Nguyễn Minh Thủy, Trần Thị Quế và Nguyễn Thị Mỹ Tuyền (2013). Phân lập, tuyển chọn và định danh nấm men trong lên men rượu vang khóm. Tap chí Khoa học Truòng Đại học Cần Tho', 25, 27-35.

Nguyễn Văn Vũ và Nguyễn Văn Thành (2018). Phân lập, tuyển chọn và định danh nấm men trong lên men rượu vang dâu Hạ Châu (Baccaurea ramiflora L.) Tap chi Khoa học Truò̀ng Đại học Cần Tho, 54(7), 22-32.

Phạm Thị Thu Thảo, Nguyễn Ngọc Anh Thư, Lê Thanh Duy, Nguyễn Ngọc Thạnh, Bùi Hoàng Đăng Long và Huỳnh Xuân Phong (2019). Phân lập và tuyển chọn nấm men có khả năng lên men rượu vang thanh long ruột đỏ (Hylocereus polyrhizus). Tap chi Khoa học và Công nghệ Việt Nam, 61(8), 54-59.

Querol, A. \& Bond, U. (2009). The complex and dynamic genomes of industrial yeasts. FEMS Microbiology Letters, 293(1), 1-10.

Radecka, D., Mukherjee, V., Mateo, R. Q., Stojiljkovic, M., Foulquié-Moreno, M. R., \& Thevelein, J. M. (2015). Looking beyond Saccharomyces: the potential of nonconventional yeast species for desirable traits in bioethanol fermentation. FEMS Yeast Research, $15(6)$, fov053.

Vũ Công Hậu (2005). Làm ruợu vang trái cây gia đình. NXB Nông nghiệp. 